\title{
Effect of different drying methods on the bioactive, microstructural, and in-vitro bioaccessibility of bioactive compounds of the pomegranate arils
}

\author{
Irem OZAY-ARANCIOGLU1,2 (D), Hatice BEKIROGLU² (D), Ayse KARADAG ${ }^{2}$ (D), Oznur SAROGLU² (D), \\ Zeynep Hazal TEKIN-ÇAKMAK² (D), Salih KARASU² (D)
}

\begin{abstract}
This study aimed to investigate the effect of different drying methods on the drying kinetic, total bioactive content, in-vitro bioaccessibility of bioactive compounds, and color and microstructural properties of pomegranate arils. Drying methods significantly affected all selected parameters of dried pomegranate arils $(\mathrm{P}<0.05)$. Freeze-drying $(\mathrm{FD})$ showed higher bioactive compounds, lower shrinkage, and better color quality than those of other samples. Ultrasound-assisted vacuum drying (UAVD) showed lower drying times, lower shrinkage, and higher bioactive compounds than vacuum drying (VD) and hot air drying (HAD). The ABTS, CUPRAC, and DPPH results were 34.53-63.71 $\mu \mathrm{mol} \mathrm{TE} / \mathrm{g}, 29.70-61.60 \mu \mathrm{mol} \mathrm{TE} / \mathrm{g}$ and 64.82-93.69\% DPPH radical scavenging activity, respectively. Also, the highest values of antioxidant capacity for all methods were obtained from the samples dried with FD followed by UAVD, VD, and HAD. The recovery of TPC in dried and fresh samples changed from $2.58 \%$ (fresh pomegranate) to $10.32 \%$ (vacuum-dried pomegranate). The recovery of TPC for freeze-dried samples $(2.62 \%)$ was closest to the fresh ones and VD showed the highest TPC recovery. This study suggested that UAVD and VD should be used as alternative methods to HAD due to higher bioactive compounds retention, better color and surface quality, and higher recovery of bioactive compounds.
\end{abstract}

Keywords: ultrasound-assisted vacuum drying; in-vitro bioaccessibility; pomegranate aril; vacuum drying.

Practical Application: In-vitro bioaccessibility of bioactive compounds of the pomegranate arils.

\section{Introduction}

Pomegranate (Punica granatum L.) is a tropical-subtropical fruit that grows in many world regions such as the USA, Anatolia, Mesopotamia, India, and Mediterranean countries and is known almost all over the world. Besides being fresh consuming, pomegranate is processed to many processes such as fruit juice, jam, marmalade, and fruit bars (Karaaslan et al., 2014). In recent years, pomegranate has been the center of attention of consumers due to its bioactive compounds such as anthocyanin, condensed tannins, and phenolic acids, which have an antioxidant, antimicrobial and anticarcinogenic effect (Calín-Sánchez et al., 2013; Fawole et al., 2012).

Due to its high moisture and sugar content, pomegranate can easily be deteriorated by microorganisms and enzyme activities. Therefore, it must be subjected to any preservation process to be consumed throughout the year. Drying is one of the most widely used methods in preserving fruits and vegetables because it has an easy application, leads to easy transportation, and higher shelf life to products (Bhandari \& Adhikari, 2008). Today, industrial methods are preferred to apply the drying process in a controlled manner rather than traditional methods such as sun drying. HAD is one of the most widely used drying methods due to its easy application. However, in HAD drying, alternative drying methods should be proposed due to the long drying time, the negative effect of the microstructural properties of fruits and vegetables, and the high degradation of bioactive components
(Kayacan et al., 2020; Turkmen et al., 2020; Wojdyło et al., 2016). Due to its low-temperature processing, FD resulted in quality products in sensory, microstructural, and bioactive properties in different food products (Chen et al., 2020; Wojdyło et al., 2016). However, despite these advantages of the FD process, the high cost of the FD process restricts the use of FD (Huang et al., 2009) in a wide range of foods. Therefore, there is a need to develop alternative methods to HAD and FD that are easy to use, have low operating costs, and provide quality products.

Vacuum drying is one of the most preferred methods to overcome the disadvantages observed in HAD. During vacuum drying, the decrease in the vapor pressure shortens the drying time and provides the opportunity to work at low temperatures (Bhandari \& Adhikari, 2008; Parikh, 2015). Besides, the absence of oxygen during vacuum drying reduces the degradation of bioactive components such as phenolic compounds and vitamins (Karaaslan et al., 2014; Karasu et al., 2015). Studies in which vacuum drying is used in combination with ultrasound, microwave, and infrared to increase vacuum drying efficiency have become widespread. Due to the cavitation and spongy effect during the ultrasound, the microstructural properties of the products can be improved, and the drying rate increases. Therefore, a trend towards ultrasound-assisted vacuum drying is increasing in the literature (Chen et al., 2020; Islam et al., 2019; Tekin \& Başlar, 2018). Many studies on drying pomegranate 
arils with HAD (Başlar et al., 2014a; Özcan et al., 2019; Süfer \& Palazoglu, 2019b), vacuum drying (Karaaslan et al., 2014), and vacuum drying with the infrared (Alaei \& Amiri Chayjan, 2015; Briki et al., 2019) and microwave (Süfer \& Palazoglu, 2019a) were studied. However, there are limited studies on drying pomegranate arils in combination with vacuum drying and ultrasound.

The color, microstructural properties, sensory properties, textural properties, and bioactive compounds content of the products change significantly during drying. Several studies were conducted on the effects of different drying types and temperatures on pomegranate arils' quality properties, such as bioactive compounds, color, and rehydration capacity (Cano-Lamadrid et al., 2017; Karaaslan et al., 2014; Süfer \& Palazoglu, 2019a). However, the in vitro accessibility properties of the bioactive compounds are also important in addition to the number of bioactive compounds during drying. There has been no study on the in vitro bioaccessibility of bioactive compounds of pomegranate arils of different drying methods. In this study, the drying behavior of pomegranate arils of different drying methods, color, total bioactive substance content, phenolic profile, and changes in in-vitro bioaccessibility properties was investigated. In this respect, our study adds many innovations to the literature.

\section{Materials and methods}

Pomegranate (Punica granatum L.) was obtained from the town of Silifke in Mersin, Turkey. Keben which is one of the most popular pomegranate cultivars in Turkey was preferred in this study. Chemicals used in the study were obtained from Merck (Darmstadt, Germany). The arils were manually separated from the peel of the pomegranate. The mean moisture content of arils was determined as $77.6 \pm 1 \%$ on a dry basis by the oven dryer at $105^{\circ} \mathrm{C}$ for 5 hours.

\subsection{Drying procedure}

Pomegranate aril samples were dried by using HAD, VD, UAVD, and FD methods. The drying process of aril samples was performed at $55^{\circ} \mathrm{C}$ by HAD, VD, and UAVD methods. For each drying method, $60 \mathrm{~g}$ samples were weighed. HAD method was conducted by using an air circulation oven (Memmert UF110, Germany) with $1.3 \mathrm{~m} \mathrm{~s}^{-1}$ constant air velocity. The UAVD method consisted of an ultrasonic water bath (Daihan-WUC$\mathrm{D} 10 \mathrm{H}$, South Korea) (amplitude $100 \%$, power intensity $\approx 1 \mathrm{~W}$ $\mathrm{cm}^{-2}$, volume $10 \mathrm{~L}$ ) and a vacuum pump (KNFN838.3KT.45.18, Germany) with 15 mbar pressure and $22 \mathrm{~L} / \mathrm{min}$ pump speed, linked to a hose (Tekin \& Başlar, 2018). The arils were dried using VD methods with the same UAVD pump system without ultrasonic application. FD method was carried out by a freezedryer (Martin Christ, Beta 1-8 LSCplus, UK) at $-55^{\circ} \mathrm{C}$ for $57 \mathrm{hr}$. The samples were frozen at $-80^{\circ} \mathrm{C}$ for 12 hours before the $\mathrm{FD}$ process. For all drying methods except FD, the samples were weighed every $15 \mathrm{~min}$ during the drying process with an analytical scale (Shimadzu, TW-423, Kyoto, Japan). The drying process was performed until water content decreased to $20 \pm 1 \%$ on a dry basis. For FD, the final moisture content was $20 \pm 1 \%$ on a dry basis. The dried samples were stored at $+4{ }^{\circ} \mathrm{C}$ until extraction.

\subsection{Extraction procedure}

The fresh and dried aril samples $(5 \mathrm{~g})$ were extracted with $20 \mathrm{~mL}$ methanol-water (50:50). The mixture was homogenized with a digital homogenizer (Daihan HG15A, Gangwondo, South Korea) at about $10000 \mathrm{rpm}$ for $3 \mathrm{~min}$. Each mixture was waited for extraction by shaking for $2 \mathrm{hr}$ at room temperature $\left(25^{\circ} \mathrm{C}\right)$. The mixture was filtered through filter paper, centrifuged at $6000 \mathrm{rpm}$ (Hettich 320R, Tuttlingen, Germany) for $10 \mathrm{~min}$, and the supernatants were filtered again. Finally, coarse supernatants were filtered through $0.45 \mu \mathrm{m}$ filters. The extracts were stored at $-20^{\circ} \mathrm{C}$ until analysis (Başlar et al., 2014a).

\subsection{Determination of total bioactive compounds}

Total phenolic content (TPC) was determined by FolinCiocalteu method described by Singleton \& Rossi (1965) and results were expressed as $\mathrm{mg} / \mathrm{g}$. Total flavonoid content (TFC) was determined using the modified method described by Zhishen et al. (1999). TFC was calculated as catechin equivalent (CE) on a dry basis. Total anthocyanin content (TAC) analysis was performed by a $\mathrm{pH}$ differential method using two buffer systems: potassium chloride buffer, $\mathrm{pH} 1.0(0.025 \mathrm{M})$, and sodium acetate buffer, pH 4.5 (0.4M) (Giusti \& Wrolstad, 2001).

The antioxidant activity was measured by using 2.2-diphenyl-1picrylhydrazyl with the DPPH method reported by Singh et al. (2002). The results were reported as mg Trolox equivalent (TE) per $g$ of the extract on a dry basis (Re et al., 1999). The cupric reducing capacity assay (CUPRAC) method was carried out according to Apak et al. (2004) procedure. The results were reported as mg Trolox equivalent (TE) on a dry basis. The radical scavenging activity of pomegranate arils against stable ABTS radical was performed as the method described by Arnao et al. (2001). The results were expressed in milligrams of the Trolox Equivalent (TE).

\subsection{In-vitro bioaccessibility of phenolic compounds}

In-vitro digestion procedure was performed according to the method Minekus et al. (2014) for fresh and dried pomegranate aril samples. Samples were taken for each time point (oral, gastric, and intestinal phase) and centrifuged at $5000 \mathrm{rpm}$ at $4{ }^{\circ} \mathrm{C}$ for $20 \mathrm{~min}$ to get supernatant. A blank sample was prepared with identical chemicals but without a food matrix, and underwent the same conditions as the samples. The supernatants were lyophilized and stored at $-20^{\circ} \mathrm{C}$ until further analysis. In-vitro bioaccessibility of phenolic compounds was carried out in triplicate.

\subsection{Color measurements}

The color values of fresh and dried aril samples were measured using a colorimeter (Kyoto, Japan). The measurements were expressed as tristimulus colorimetric measurements, that is, $\mathrm{L}^{*}$ (whiteness/ darkness), $\mathrm{a}^{*}$ (redness/greenness), and $\mathrm{b}^{*}$ (yellowness/blueness). The aril colors were measured at three random positions and the mean values of the obtained data were defined as the color values. The total color change $(\Delta \mathrm{E})$ was calculated according to the following Equation 1 as a dry basis: 


$$
\Delta \mathrm{E}=\sqrt{\Delta \mathrm{L}^{2}+\Delta \mathrm{a}^{2}+\Delta \mathrm{b}^{2}}
$$

\subsection{Microstructure analysis}

Structural characterization of aril samples was performed by Yildiz Technical University Central Laboratory with Zeiss EVO $^{\circledR}$ LS 10 Scanning Electron Microscope (SEM). For this purpose, the dried pomegranate aril samples were coated with gold plating to provide a reflective surface for the electron beam and imaged under a $15 \mathrm{kV}$ microscope.

\subsection{Statistical analysis}

Statistical analysis results were reported as the mean values of the duplicates with their standard deviations. The results were analyzed using the one-way analysis of variance (ANOVA) using the JMP ver. 9 software (SAS Institute) and the means were compared by Student's t-test at a significance level of 0.05 .

\section{Results and discussion}

\subsection{Drying curve}

Figure 1 shows the drying behavior of pomegranate arils dried by different drying methods. In all drying methods, while moisture loss was observed at the beginning, there was a decrease in the moisture transfer rate towards the end of the drying process. The decrease in moisture transfer rate at the

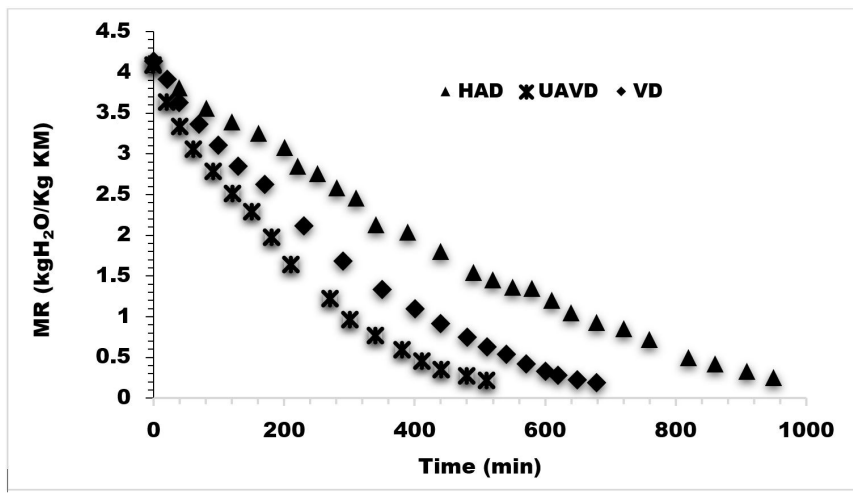

Figure 1. Drying characteristic of pomegranate arils under different drying methods (HAD: Hot air drying; UAVD: Ultrasound assisted vacuum drying; VD: Vacuum drying). end of the drying process can be explained by the fact that the constant drying period is replaced by the diffusion drying period.

When the drying curves were examined, the diffusion period was longer in HAD than VD and UAVD. Drying times were determined as 950,650 , and 510 min for HAD, VD, and UAVD, respectively. UAVD exhibited almost 2 times less drying time than HAD. Such a decrease in drying times of fruits rich in heat-sensitive bioactive components such as pomegranate arils is very important. This reduction in drying time in UAVD can be explained by the combination of vacuum application with the ultrasound process. The compression expansion resulting from the ultrasound process causes the sponge effect that causes microcapillaries to form in the food matrix. The cavitation resulting from the application of ultrasound has enabled the water to diffuse more easily and quickly towards the surface from these microcapillaries in the cell plant matrix. Thus, the application of ultrasound may have caused a significant increase in diffusion rate due to the spongy and cavitation effect (Başlar et al., 2014b; Liu et al., 2019). These results show that the combined application of ultrasound and vacuum can be used as an alternative to the conventional method in terms of reducing the drying time of pomegranate arils. The decrease in drying time with the application of ultrasound has been reported from other studies (Kayacan et al., 2020; Tekin \& Başlar, 2018).

\subsection{Total bioactive compounds}

Table 1 showed the effects of different drying methods on the total bioactive compounds. Table 1 showed that lower bioactive compounds were observed from the dried samples compared to fresh ones except for FD dried samples. TPC, TFC, and TA values of the FD dried sample were higher than that of the fresh samples. These results indicated that all drying methods except FD caused degradation in bioactive compounds of dried samples. Similar results were also reported from different studies conducted on pomegranate arils drying (Başlar et al., 2014a; Calín-Sánchez et al., 2013). Different drying methods significantly affected the total amount of bioactive compounds $(\mathrm{p}<0.05)$.

TPC amounts of the samples were found as $6.13-8.22 \mathrm{mg} / \mathrm{g}$. The highest and lowest TPC amounts were obtained from samples dried by FD and HAD, respectively. TPC values of samples dried with UAVD and VD were significantly higher than HAD $(p<0.05)$. The higher retention of phenolic compounds in FD dried

Table 1. Change in bioactive properties of pomegranate during the drying process.

\begin{tabular}{ccccccccc}
\hline Methods & $\begin{array}{c}\text { Temp. } \\
\left({ }^{\circ} \mathbf{C}\right)\end{array}$ & $\begin{array}{c}\text { Drying Time } \\
(\mathbf{m i n})\end{array}$ & $\begin{array}{c}\text { TPC } \\
(\mathbf{m g ~ G A E} / \mathbf{g})\end{array}$ & $\begin{array}{c}\text { TFC } \\
(\mathbf{m g ~ C E} / \mathbf{g})\end{array}$ & $\begin{array}{c}\text { TAC }(\mathbf{m g} \text { Cyanidin- } \\
\text { 3-glucoside/ 100 g) }\end{array}$ & $\begin{array}{c}\text { ABTS } \\
(\boldsymbol{\mu m o l ~ T E} / \mathbf{g})\end{array}$ & $\begin{array}{c}\text { CUPRAC } \\
(\boldsymbol{\mu m o l ~ T E} / \mathbf{g})\end{array}$ & $\begin{array}{c}\text { DPPH }(\%) \\
\text { Fresh aril }\end{array}$ \\
& & $8.22 \pm 0.01^{\mathrm{a}}$ & $0.49 \pm 0.06^{\mathrm{a}}$ & $92.87 \pm 0.88^{\mathrm{b}}$ & $56.11 \pm 2.10^{\mathrm{b}}$ & $59.87 \pm 0.05^{\mathrm{b}}$ & $87.246 \pm 1.216^{\mathrm{b}}$ \\
HAD & $55^{\circ} \mathrm{C}$ & 950 & $6.13 \pm 0.20^{\mathrm{e}}$ & $0.33 \pm 0.01^{\mathrm{d}}$ & $41.48 \pm 0.57^{\mathrm{e}}$ & $34.53 \pm 0.28^{\mathrm{e}}$ & $29.70 \pm 0.38^{\mathrm{e}}$ & $64.821 \pm 4.531^{\mathrm{e}}$ \\
VD & $55^{\circ} \mathrm{C}$ & 650 & $6.39 \pm 0.25^{\mathrm{d}}$ & $0.39 \pm 0.03^{\mathrm{c}}$ & $59.31 \pm 0.06^{\mathrm{d}}$ & $41.71 \pm 2.05^{\mathrm{c}}$ & $33.11 \pm 0.95^{\mathrm{d}}$ & $75.715 \pm 4.291^{\mathrm{d}}$ \\
UAVD & $55^{\circ} \mathrm{C}$ & 510 & $6.88 \pm 0.27^{\mathrm{c}}$ & $0.47 \pm 0.01^{\mathrm{b}}$ & $71.28 \pm 0.62^{\mathrm{c}}$ & $37.75 \pm 1.94^{\mathrm{d}}$ & $49.45 \pm 1.84^{\mathrm{c}}$ & $84.510 \pm 0.640^{\mathrm{c}}$ \\
FD & $-50^{\circ} \mathrm{C}$ & 3420 & $7.88 \pm 0.01^{\mathrm{b}}$ & $0.49 \pm 0.04^{\mathrm{a}}$ & $101.75 \pm 0.58^{\mathrm{a}}$ & $63.71+4.32^{\mathrm{a}}$ & $61.61 \pm 0.63^{\mathrm{a}}$ & $93.695 \pm 0.640^{\mathrm{a}}$ \\
\hline
\end{tabular}

Drying methods; HAD: hot air drying; VD: vacuum drying; UAVD: ultrasound-assisted vacuum drying; FD: freeze drying; TPC: Total phenolic content and results were expressed as gallic acid equivalents per $\mathrm{g}$ of fresh matter (mg GAE/g); TFC: Total flavanoid content and results were calculated as catechin equivalent (mg CE/g); TAC: Total anthocyanin content of samples and results were expressed as mg cyanidin-3-glucoside/L; ABTS and CUPRAC were expressed as Trolox equivalent; DPPH was described as the percentage of scavenging effect. Different lowercase letter in the same line indicates differences between samples subjected to different drying methods $(\mathrm{P}<0.05)$. ${ }^{\mathrm{a} D a t a}$ are expressed as mean \pm standard deviation. ${ }^{b}$ Values followed by different alphabets in the same column are differ significantly $(\mathrm{p}<0.05)$. 
samples were also reported from the other studies (Chen et al., 2020; Gölükcü, 2015; Hawlader et al., 2006; Turkmen et al., 2020). The high amount of TPC in samples dried with FD can be explained by the low drying temperature and vacuum conditions (Chen et al., 2020). The low TPC level in the samples dried with $\mathrm{HAD}$ can be explained by the degradation of phenolic compounds during the long drying period. Drying time in VD and UAVD is significantly less than HAD. Also, these drying methods were carried out under vacuum conditions. Low drying time and vacuum conditions in VD and UAVD may have caused less degradation of phenolic compounds than HAD.

When we compare VD with UAVD, the level of the phenolic compounds of UAVD is significantly higher than that of VD. The cavitation effect during UAVD may have damaged the plant matrix more and enabled the phenolic compounds bounded to the matrix to be separated easily. Besides, the ultrasound process may have caused the formation of micro-capillaries in the matrix and thus the phenolic compounds to be extracted easily (Tekin \& Başlar, 2018). The higher retention of phenolic compounds in ultrasound-assisted technique compared to HAD were also reported from other studies (Kayacan et al., 2020; Kroehnke et al., 2018; Tekin \& Başlar, 2018; Tekin et al., 2017; Turkmen et al., 2020). TFC and TAC values of the dried and fresh samples were $0.33-0.49 \mathrm{mg} / \mathrm{g}$ and $41.48-101.75 \mathrm{mg} / 100 \mathrm{~g}$, respectively. The highest and lowest value of TFC and TAC were obtained from FD and HAD. The change in TFC and TAC values according to the drying method was similar to that of TPC. It can be explained that most of the phenolic compounds in pomegranate consist of flavonoids such as anthocyanin.

The antioxidant capacity values of the samples were analyzed by ABTS, DPPH, and CUPRAC methods. The ABTS, CUPRAC, and DPPH results were 34.53-63.71 $\mu \mathrm{mol} \mathrm{TE} / \mathrm{g}, 29.70-61.60 \mu \mathrm{mol} \mathrm{TE} / \mathrm{g}$ and $64.82-93.69 \% \mathrm{DPPH}$ radical scavenging activity respectively. In similar to total bioactive compounds value, the highest values of antioxidant capacity for all methods were obtained from the samples dried with FD. For CUPRAC and DPPH methods, as in TPC analysis, the highest antioxidant capacity value after FD was obtained from UAVD, while for the ABTS method, the highest value after FD was obtained from VD. This result suggests that antioxidant capacity values should be evaluated with different methods. The lowest antioxidant capacity value was obtained from the sample dried with HAD in all methods. This result can be explained by the degradation of phenolic compounds with antioxidant capacity in the long drying period and the presence of oxygen during HAD (Hamid et al., 2020). Therefore, these results indicated that UAVD can be preferred as an alternative method to HAD in terms of preserving total bioactive compounds and antioxidant activity.

\subsection{In-vitro digestion procedure}

Effect of in vitro digestion on the total phenolic content (TPC), total flavonoid content (TFC), total anthocyanin content (TAC) and antioxidant activities of fresh, freeze-dried, vacuum dried, oven-dried and ultrasound-assisted vacuum dried pomegranate were given in Table 2. The changes in TPC, TFC, TAC, and antioxidant activities through in-vitro digestion would help to understand the bioaccessibility of bioactive compounds. As expected, the amount of TPC, TFC, TAC, and antioxidant values at the oral phase was lower than the total phenolic content of the undigested sample due to poor solubility of phenolics in salivary fluid and the short duration of this phase (Ucar \& Karadag, 2019).

Compare to the oral phase, except oven and vacuum dried samples, TPC of other dried pomegranates was significantly increased in the gastric phase, and it was most prominent for the freeze-dried samples, increased from 4.80 to $9.24 \mathrm{mg} \mathrm{GAE} / \mathrm{g}$. In the oven-dried sample, the difference of TPC between the oral and gastric phase was not significant. TFC content of freezeand oven-dried samples showed similar behavior from oral to gastric phase, whereas in other samples TFC content was not changed significantly. In terms of TAC, except for fresh samples, all dried samples showed an increased amount of anthocyanin at the end of the gastric digestion phase compared to the oral phase. After the intestinal phase, TFC and TAC content was detected at none of IN samples (free soluble dialyzable fraction), and the TPC content of IN samples was always lower than that of OUT samples (intestinal digest). The recovery of TPC in our samples changed from $2.58 \%$ (fresh pomegranate) to $10.32 \%$ (vacuum-dried pomegranate). Interestingly the recovery of TPC for freeze-dried samples (2.62\%) was closest to the fresh ones where the fruit morphology/structure was mostly protected.

The bioaccessibility of phenolic compounds would be increased when the drying method leads to the disruption of the plant matrix and enhance the release of phenolic compounds. Similarly, in our previous study, we demonstrated that the bioaccessibility of phenolics in persimmon fruit was affected by the drying method applied, and the lowest recovery of phenolics was observed in fresh fruits, followed by freeze-dried samples and the highest recovery was obtained with hot airdried persimmons (Kayacan et al., 2020). Dalmau et al. (2017) investigated the effect of convective drying, freeze-drying, and freezing on in vitro digestion of apple and they concluded that not only the initial TPC value but also the structure of the food matrix, may be important in the release of nutrients from food matrices during digestion. In the study of Ucar \& Karadag (2019), a comparable trend was also reported, the extractability of phenolics in simulated digestion fluids was higher for vacuum dried oyster mushrooms compared to freeze-dried samples, meaning that the physical structure of the food matrix would also influence the diffusion rate of digestion fluids.

In plants, in addition to their soluble forms, phenolic compounds also exist inbound to macromolecules in the matrix, and they can be released with the help of enzyme and acidic $\mathrm{pH}$ in the simulated gastric system. The higher recovery of phenolic compounds after gastric digestion of pomegranate products was also observed in other studies (Mosele et al., 2015; Sengul et al., 2014). David et al. (2019) also reported that the increase in total anthocyanin content of Cornelian cherry fruit extract after gastric digestion was related to the destruction of matrix and release of monomeric anthocyanins from the polymers present in the extract. In our study, after the intestinal phase anthocyanin content could not be determined, due to the susceptibility of anthocyanins to higher $\mathrm{pH}$ levels. A significant reduction of anthocyanins was observed by Pérez-Vicente et al. 
Table 2. Change in the total phenolic content (TPC), total flavonoid content (TFC), antioxidant activities of fresh, pomegranate arils dried with $\mathrm{FD}, \mathrm{VD}, \mathrm{HAD}$ and UAVD during in-vitro gastrointestinal digestion.

\begin{tabular}{|c|c|c|c|c|c|c|c|}
\hline \multicolumn{3}{|c|}{ Methods } & $\begin{array}{l}\text { TPC (mg } \\
\text { GAE/g) }\end{array}$ & TFC (mg CE/g) & $\begin{array}{c}\text { ABTS }(\mu \mathrm{mol} \\
\text { TE/g) }\end{array}$ & $\begin{array}{l}\text { CUPRAC }(\mu \mathrm{mol} \\
\text { TE } / \mathrm{g})\end{array}$ & $\begin{array}{c}\text { Anthocyanin (mg Cyanidin-3- } \\
\text { glucoside/ } 100 \mathrm{~g})\end{array}$ \\
\hline \multirow{6}{*}{$\begin{array}{l}\text { Vacuum Dried } \\
\text { Pomegranate } \\
55^{\circ} \mathrm{C}\end{array}$} & \multicolumn{2}{|l|}{ Undigested } & $6.39 \pm 0.25^{\mathrm{d}}$ & $0.39 \pm 0.03^{b c}$ & $41.71 \pm 2.05^{\mathrm{b}}$ & $33.11 \pm 0.95^{\mathrm{b}}$ & $59.31 \pm 0.06^{\mathrm{d}}$ \\
\hline & \multicolumn{2}{|l|}{ Oral } & $5.63 \pm 0.12^{c}$ & $0.92 \pm 0.19^{\mathrm{d}}$ & $101.64 \pm 1.40^{c}$ & $88.65 \pm 5.08^{c}$ & $3.80 \pm 0.34^{\mathrm{b}}$ \\
\hline & \multicolumn{2}{|l|}{ Gastric } & $5.11 \pm 0.29^{c}$ & $0.66 \pm 0.10^{\mathrm{cd}}$ & $11.81 \pm 1.44^{\mathrm{a}}$ & $95.86 \pm 5.92^{\mathrm{c}}$ & $5.73 \pm 0.75^{c}$ \\
\hline & Intestinal & OUT & $4.09 \pm 0.27^{b}$ & $0.29 \pm 0.06^{\mathrm{b}}$ & $140.32 \pm 3.13^{\mathrm{d}}$ & $139.46 \pm 2.67^{\mathrm{d}}$ & ND \\
\hline & & IN & $0.66 \pm 0.04^{\mathrm{a}}$ & ND & $7.02 \pm 0.03^{\mathrm{a}}$ & $7.84 \pm 1.42^{\mathrm{a}}$ & ND \\
\hline & \multicolumn{2}{|c|}{ Recovery (\%) } & 10.32 & - & 16.83 & 23.67 & - \\
\hline \multirow{6}{*}{$\begin{array}{l}\text { Oven-Dried } \\
\text { Pomegranate } \\
55^{\circ} \mathrm{C}\end{array}$} & \multicolumn{2}{|c|}{ Undigested } & $6.13 \pm 0.20^{c}$ & $0.33 \pm 0.01^{\mathrm{b}}$ & $34.53 \pm 0.28^{\mathrm{b}}$ & $29.70 \pm 0.38^{\mathrm{b}}$ & $41.48 \pm 0.57^{\mathrm{d}}$ \\
\hline & \multicolumn{2}{|l|}{ Oral } & $4.51 \pm 0.54^{\mathrm{b}}$ & $0.41 \pm 0.02^{\mathrm{b}}$ & $64.03 \pm 6.28^{c}$ & $75.46 \pm 6.84^{c}$ & $1.41 \pm 0.36^{\mathrm{b}}$ \\
\hline & \multicolumn{2}{|l|}{ Gastric } & $3.72 \pm 0.52^{\mathrm{b}}$ & $0.60 \pm 0.080^{c}$ & $8.14 \pm 0.08^{\mathrm{a}}$ & $72.68 \pm 4.69^{c}$ & $4.17 \pm 0.61^{\mathrm{c}}$ \\
\hline & \multirow[t]{2}{*}{ Intestinal } & OUT & $3.50 \pm 0.64^{\mathrm{b}}$ & $0.71 \pm 0.04^{\mathrm{c}}$ & $118.33 \pm 10.23^{\mathrm{d}}$ & $132.52 \pm 3.39^{\mathrm{d}}$ & ND \\
\hline & & $\mathrm{IN}$ & $0.47 \pm 0.08^{\mathrm{a}}$ & ND & $5.57 \pm 0.38^{\mathrm{a}}$ & $5.52 \pm 0.81^{\mathrm{a}}$ & ND \\
\hline & \multicolumn{2}{|c|}{ Recovery (\%) } & 7.68 & - & 16.13 & 18.58 & - \\
\hline \multirow{6}{*}{$\begin{array}{l}\text { Ultrasound- } \\
\text { Assisted } \\
\text { Vacuum } \\
\text { Drying-55 }{ }^{\circ} \mathrm{C}\end{array}$} & \multicolumn{2}{|c|}{ Undigested } & $6.88 \pm 0.27^{\mathrm{e}}$ & $0.47 \pm 0.01^{\mathrm{c}}$ & $37.75 \pm 1.94^{\mathrm{b}}$ & $49.45 \pm 1.84^{\mathrm{b}}$ & $71.28 \pm 0.62^{\mathrm{d}}$ \\
\hline & \multicolumn{2}{|l|}{ Oral } & $3.95 \pm 0.02^{\mathrm{b}}$ & $0.44 \pm 0.04^{\mathrm{c}}$ & $67.27 \pm 4.96^{c}$ & $61.66 \pm 7.84^{b}$ & $7.99 \pm 0.11^{\mathrm{b}}$ \\
\hline & \multicolumn{2}{|l|}{ Gastric } & $5.10 \pm 0.22^{c}$ & $0.41 \pm 0.07^{c}$ & $12.81 \pm 0.95^{\mathrm{a}}$ & $127.83 \pm 6.47^{\mathrm{d}}$ & $12.03 \pm 1.00^{c}$ \\
\hline & \multirow[t]{2}{*}{ Intestinal } & OUT & $6.03 \pm 0.04^{\mathrm{d}}$ & $0.26 \pm 0.03^{\mathrm{b}}$ & $116.94 \pm 2.50^{\mathrm{d}}$ & $109.78 \pm 5.00^{c}$ & ND \\
\hline & & IN & $0.66 \pm 0.06^{\mathrm{a}}$ & ND & $8.69 \pm 0.67^{a}$ & $24.91 \pm 1.58^{\mathrm{a}}$ & ND \\
\hline & \multicolumn{2}{|c|}{ Recovery (\%) } & 9.59 & - & 23.01 & 50.37 & - \\
\hline \multirow{6}{*}{$\begin{array}{l}\text { Freeze Dried } \\
\text { Pomegranate }\end{array}$} & \multicolumn{2}{|c|}{ Undigested } & $7.88 \pm 0.01^{\mathrm{c}}$ & $0.49 \pm 0.04^{\mathrm{b}}$ & $63.71+4.32^{\mathrm{b}}$ & $61.61 \pm 0.63^{\mathrm{b}}$ & $101.75 \pm 0.58^{\mathrm{d}}$ \\
\hline & \multicolumn{2}{|l|}{ Oral } & $4.80 \pm 0.25^{\mathrm{b}}$ & $0.43 \pm 0.11^{\mathrm{b}}$ & $71.71 \pm 9.15^{\mathrm{b}}$ & $65.16 \pm 4.77^{\mathrm{b}}$ & $8.26 \pm 2.36^{\mathrm{b}}$ \\
\hline & \multicolumn{2}{|l|}{ Gastric } & $9.24 \pm 1.41^{\mathrm{d}}$ & $0.86 \pm 0.10^{c}$ & $9.51 \pm 0.80^{\mathrm{a}}$ & $152.12 \pm 9.70^{c}$ & $65.17 \pm 1.04^{c}$ \\
\hline & \multirow[t]{2}{*}{ Intestinal } & OUT & $5.32 \pm 0.88^{\mathrm{bc}}$ & $0.31 \pm 0.06^{\mathrm{b}}$ & $129.25 \pm 32.06^{c}$ & $165.00 \pm 12.84^{\mathrm{c}}$ & ND \\
\hline & & IN & $0.23 \pm 0.02^{\mathrm{a}}$ & ND & $3.90 \pm 0.10^{\mathrm{a}}$ & $23.94 \pm 2.26^{\mathrm{a}}$ & ND \\
\hline & \multicolumn{2}{|c|}{ Recovery (\%) } & 2.92 & - & 6.12 & 38.85 & - \\
\hline \multirow{6}{*}{$\begin{array}{l}\text { Fresh } \\
\text { Pomegranate }\end{array}$} & \multicolumn{2}{|c|}{ Undigested } & $8.22 \pm 0.01^{\mathrm{e}}$ & $0.39 \pm 0.06^{c}$ & $56.11 \pm 2.10^{c}$ & $29.87 \pm 0.05^{\mathrm{b}}$ & $62.87 \pm 0.88^{c}$ \\
\hline & \multicolumn{2}{|l|}{ Oral } & $2.84 \pm 0.12^{\mathrm{c}}$ & $0.41 \pm 0.02^{c}$ & $21.87 \pm 5.06^{\mathrm{a}}$ & $32.15 \pm 1.79^{b}$ & $41.97 \pm 1.11^{\mathrm{b}}$ \\
\hline & \multicolumn{2}{|l|}{ Gastric } & $1.65 \pm 0.26^{\mathrm{b}}$ & $0.68 \pm 0.04^{\mathrm{d}}$ & $27.92 \pm 3.29^{\mathrm{a}}$ & $29.62 \pm 2.84^{\mathrm{b}}$ & $42.09 \pm 8.13^{\mathrm{b}}$ \\
\hline & \multirow[t]{2}{*}{ Intestinal } & OUT & $3.94 \pm 0.41^{\mathrm{d}}$ & $0.28 \pm 0.01^{\mathrm{b}}$ & $44.06 \pm 3.67^{b}$ & $48.96 \pm 1.45^{\mathrm{c}}$ & ND \\
\hline & & IN & $0.22 \pm 0.05^{\mathrm{a}}$ & ND & $23.12 \pm 0.86^{\mathrm{a}}$ & $6.39 \pm 0.53^{\mathrm{a}}$ & ND \\
\hline & \multicolumn{2}{|c|}{ Recovery (\%) } & 2.67 & - & 41.20 & 21.39 & - \\
\hline
\end{tabular}

${ }^{*}$ HAD: hot air drying; VD: vacuum drying; UAVD: ultrasound assisted vacuum drying; FD: freeze drying; IN: a dialyzable fraction of intestinal digestion; OUT: undialyzable fraction of intestinal digestion, ND: no data. Different lowercase letter in the same line indicates differences between samples subjected to different drying methods $(\mathrm{P}<0.05)$.

(2002) after the intestinal phase during the in vitro digestion of pomegranate juice.

The antioxidant activity of the pomegranate samples was studied by ABTS and CUPRAC antioxidant assays during in vitro digestion. Compared to the oral stage, ABTS activity of dried pomegranate samples was reduced after the gastric stage and increased at the intestinal phase, whereas for fresh sample it did not change at the gastric phase and increased after the intestinal stage. An increase in CUPRAC values at the intestinal phase was also observed in all samples. The transition from acidic to alkaline environment was commonly thought to improve the ability of proton donation of phenolic that would enhance their antioxidant characteristics. Similarly, in the study of Ucar \& Karadag (2019). ABTS activity of digested mushroom samples after intestinal step was higher that than of gastric step. A significant increase in ABTS activity was observed after the intestinal digestion of yellow-colored pea hulls (Ma et al., 2021).

\subsection{Color and surface characteristic of pomegranate arils}

Table 3 showed the $L^{*}, a^{*}$, and $b^{*}$ color parameters of fresh and dried pomegranate arils samples. In addition, $\Delta \mathrm{E}$ values were calculated for each drying method to observe the perceptible color difference. The drying methods significantly affected $L^{*}$, $a^{*}$, and $b^{*}$ values . $L^{*}$ values of the samples ranged from 26 to 41. $L^{*}$ values did not change significantly in VD drying, while $L^{*}$ values were decreased significantly in UAVD and HAD drying and increased in the FD drying method $(\mathrm{p}<0.05)$. The $\mathrm{a}^{\star}$ value of the samples varied between 12.1 and 18.7. HAD and FD led to a significant increase in the $\mathrm{a}^{*}$ value $(\mathrm{p}<0.05)$ while UAVD and VD did not significantly change in $a^{\star}$ value $(p>0.05)$. The longer drying period observed from HAD than the VD and UAVD might have caused higher anthocyanin degradation and nonenzymatic browning (Guiné \& Barroca, 2012). The higher L* and $\mathrm{a}^{\star}$ value for FD dried samples might be due to low drying temperature and vacuum condition in FD (Gao et al., 2012). 


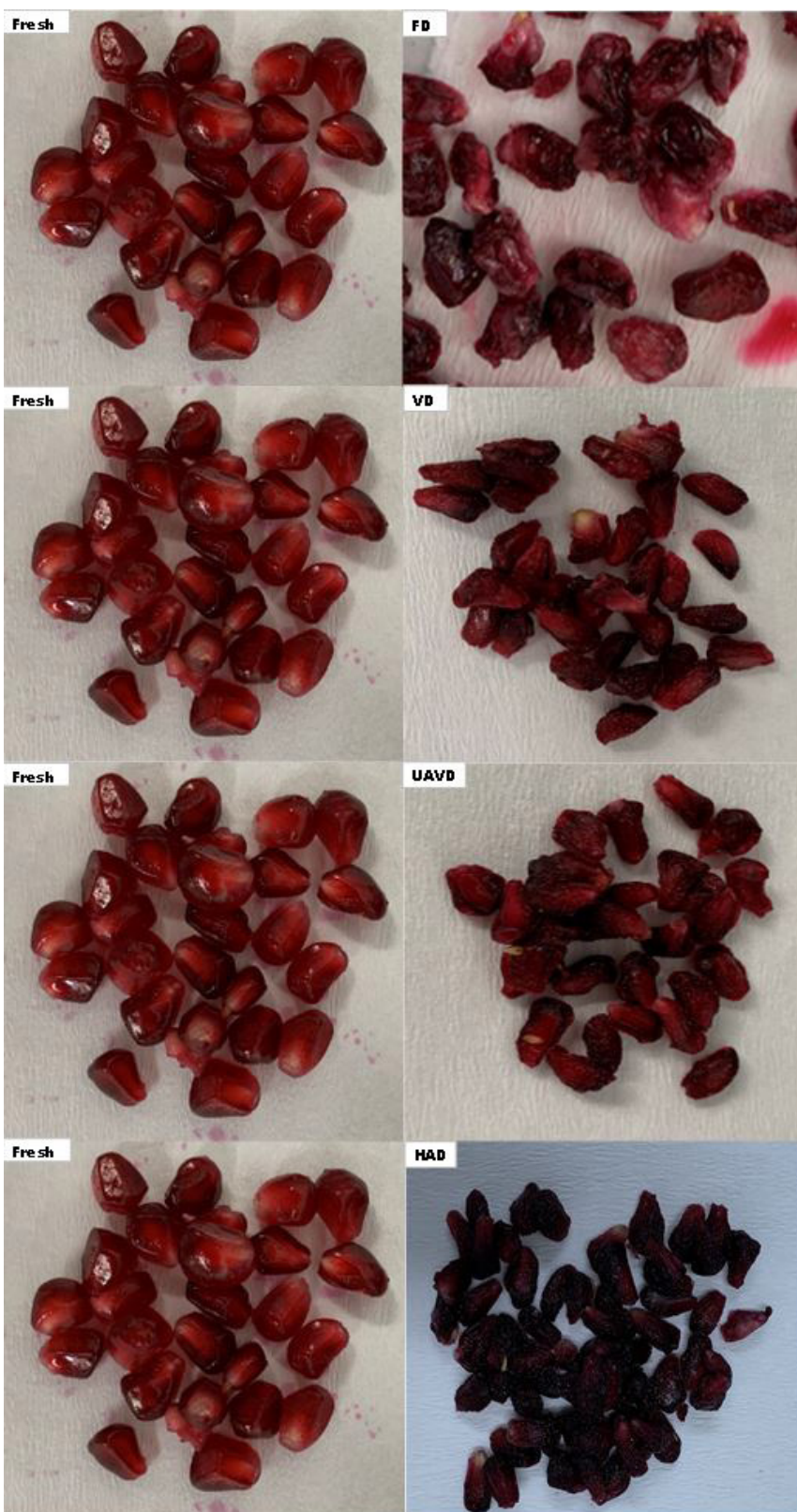

Figure 2. The pictures of the dried and fresh samples (Hot air drying (HAD), Ultrasound assisted vacuum drying (UAVD), Vacuum drying (VD) pomegranate aril samples, Freeze drying (FD).
The anthocyanin degradation and non-enzymatic browning were not observed and the anthocyanin concentrations increased after removing water. Therefore, the higher $a^{\star}$ value was observed after FD drying. The higher $\mathrm{L}^{*}, \mathrm{a}^{*}$, and $\mathrm{b}^{*}$ values in FD than those of HAD, UAVD, and VD can be explained by the fact that the higher temperature and long drying process during these methods resulted anthocyanin and other pigment degradation and non-enzymatic browning.

The higher L value observed from FD could be due to preserving of microstructural properties, which is closely related to brightness of samples (Chen et al., 2020). Also, since the UAVD and VD methods provide an oxygen-free environment and low drying times, the color pigments may be less degraded and non-enzymatic browning minimized (Kayacan et al., 2020; Orikasa et al., 2014). Therefore, an insignificant change in $\mathrm{a}^{*}$ value might have occurred in UAVD and VD compared to $\mathrm{HAD}$. The higher change in color parameters were also reported from previously published studies. $\Delta \mathrm{E}$ values differed between 2.82 and 11.25. The lowest and highest $\Delta \mathrm{E}$ values were observed in $\mathrm{VD}$ and $\mathrm{FD}$, respectively. $\triangle \mathrm{E}$ value of more than 5 indicates a perceptible change after the drying process. The $\Delta \mathrm{E}$ values in HAD and FD were higher than 5 , indicating that perceptible change occurred in FD and HAD dried samples.

Figure 2 showed a picture of the dried and fresh samples. As seen, HAD showed very dark images than fresh samples while FD resulted in lighter images than fresh samples. These results suggested that $\Delta \mathrm{E}$ value could be successfully used in comparing the samples HAD, UAVD and VD while it should not be considered only one factor in the evaluation of color differences FD and other methods.

Surface characteristics of the dried samples were determined by SEM images (Figure 3). As can be seen, no shrinkage was observed in the samples dried with FD while shrinkage was observed in the samples dried with other methods, especially in HAD dried samples. Shrinkage affects dried quality such as dehydration capacity, texture, and surface cracking of food material surface (Mahiuddin et al., 2018). The shrinkage also has a negative effect on consumer preference. The shrinkage is occurred by microstructural stress, which is promoted by the moisture gradient within the foods. The microstructural stress caused the deformation of food material and shrinkage to occur (Khan et al., 2016; Mahiuddin et al., 2018). The higher drying period

Table 3. Change in color parameters of pomegranate arils during the drying process.

\begin{tabular}{cccccc}
\hline \multirow{2}{*}{ Color Parameters } & Fresh Pomegranate & \multicolumn{3}{c}{ Dried Pomegranate } \\
\cline { 3 - 6 } & & UAVD & VD & HAD & FD \\
\hline$L^{*}$ & $32.7 \pm 1.13^{\mathrm{b}}$ & $29.2 \pm 0.71^{\mathrm{c}}$ & $32.7 \pm 0.43^{\mathrm{b}}$ & $26.1 \pm 0.70^{\mathrm{d}}$ & $41.9 \pm 0.79^{\mathrm{a}}$ \\
$a^{*}$ & $12.9 \pm 1.79^{\mathrm{c}}$ & $13.0 \pm 1.30^{\mathrm{c}}$ & $12.1 \pm 1.28^{\mathrm{c}}$ & $15.0 \pm 1.41^{\mathrm{b}}$ & $18.7 \pm 0.98^{\mathrm{a}}$ \\
$b^{*}$ & $4.8 \pm 1.00^{\mathrm{a}}$ & $2.9 \pm 1.62^{\mathrm{ab}}$ & $2.1 \pm 0.30^{\mathrm{b}}$ & $5.6 \pm 1.52^{\mathrm{a}}$ & $1.9 \pm 0.28^{\mathrm{b}}$ \\
$\Delta \mathrm{E}$ & & $4.16 \pm 0.22^{\mathrm{c}}$ & $2.82 \pm 0.10^{\mathrm{d}}$ & $6.97 \pm 0.18^{\mathrm{b}}$ & $11.25 \pm 1.00^{\mathrm{a}}$ \\
\hline
\end{tabular}

HAD: hot air drying; VD: vacuum drying; UAVD: ultrasound assisted vacuum drying; FD: freeze drying. Different lowercase letter in the same line indicates differences between samples subjected to different drying methods $(\mathrm{P}<0.05)$. 


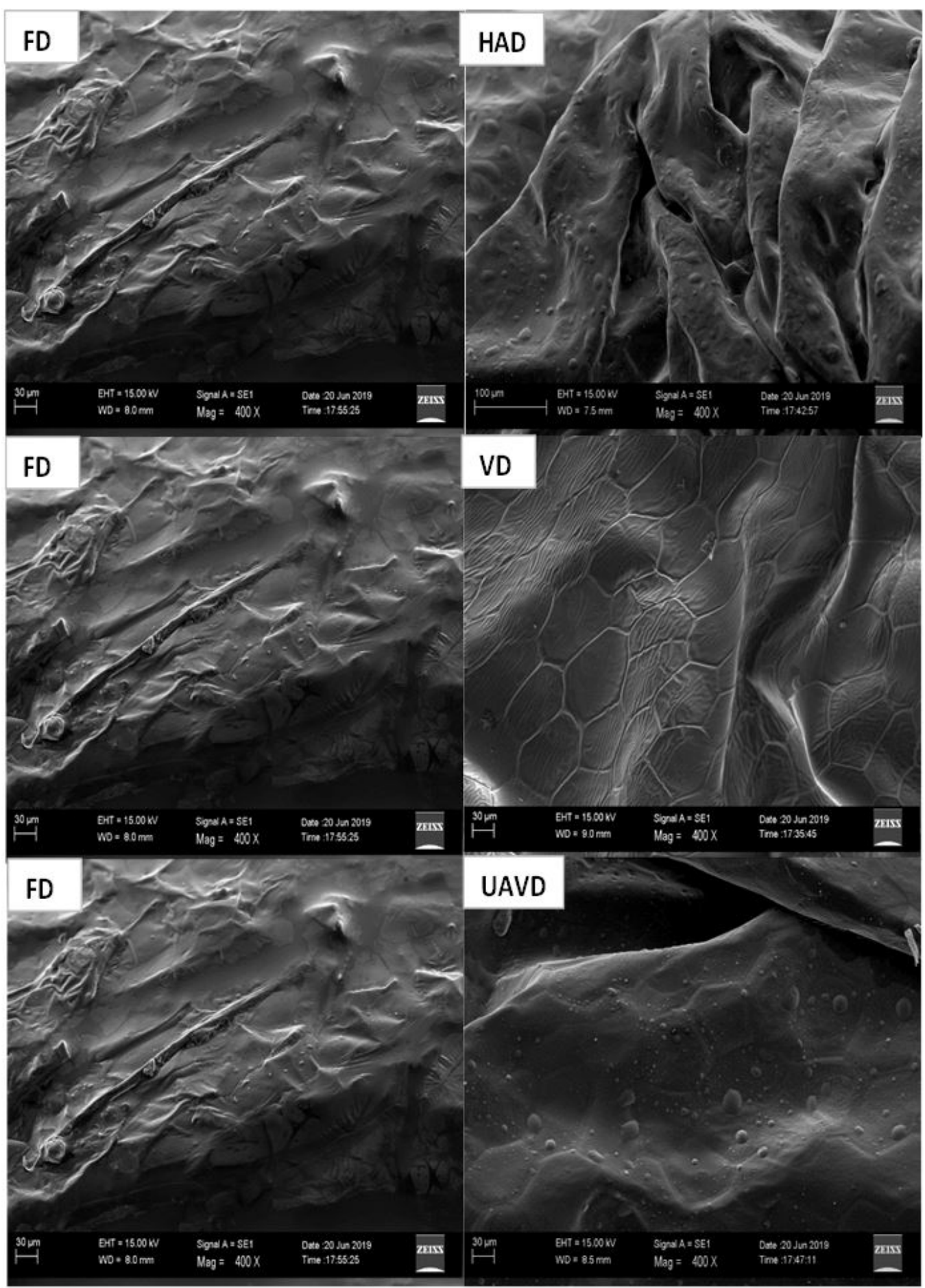

Figure 3. Surface characteristic of dried samples by SEM images (Hot air drying (HAD), Ultrasound assisted vacuum drying (UAVD), Vacuum drying (VD) persimmon samples, Freeze drying (FD).

and non-uniform drying especially in falling rate drying periods might have resulted in more shrinkage in HAD dried sample.

\section{Conclusion}

This study investigated the effect of different drying methods on drying kinetic, total bioactive compounds, in-vitro bioaccessibility of bioactive compounds, and color and surface characteristics of dried pomegranate arils. The drying methods significantly affected all parameters. The FD showed higher bioactive compounds, lower shrinkage, and better color quality than those of other samples. However, FD showed lower bioactive compound recovery than that of other samples. HAD led to higher degradation on bioactive compounds, showed higher drying time than that of VD and UAVS, and showed the highest color change and shrinkage. This study suggested that UAVD 
should be used as an alternative method due to higher bioactive compounds retention, lower drying time, better surface and color characteristics than $\mathrm{HAD}$, and higher bioactive compounds recovery than FD.

\section{References}

Alaei, B., \& Amiri Chayjan, R. (2015). Drying characteristics of pomegranate arils under near infrared-vacuum conditions. Journal of Food Processing and Preservation, 39(5), 469-479. http://dx.doi. org/10.1111/jfpp.12252.

Apak, R., Güçlü, K., Özyürek, M., \& Karademir, S. E. (2004). Novel total antioxidant capacity index for dietary polyphenols and vitamins $\mathrm{C}$ and $\mathrm{E}$, using their cupric ion reducing capability in the presence of neocuproine: CUPRAC method. Journal of Agricultural and Food Chemistry, 52(26), 7970-7981. http://dx.doi.org/10.1021/jf048741x. PMid:15612784.

Arnao, M. B., Cano, A., Alcolea, J. F., \& Acosta, M. (2001). Estimation of free radical-quenching activity of leaf pigment extracts. Phytochemical Analysis: An International Journal of Plant Chemical and Biochemical Techniques, 12(2), 138-143. http://dx.doi.org/10.1002/pca.571. PMid:11705243.

Başlar, M., Karasu, S., Kilicli, M., Us, A. A., \& Sagdic, O. (2014a). Degradation kinetics of bioactive compounds and antioxidant activity of pomegranate arils during the drying process. International Journal of Food Engineering, 10(4), 839-848. http://dx.doi.org/10.1515/ ijfe-2014-0080.

Başlar, M., Kılıçlı, M., Toker, O. S., Sağdıç, O., \& Arici, M. (2014b). Ultrasonic vacuum drying technique as a novel process for shortening the drying period for beef and chicken meats. Innovative Food Science \& Emerging Technologies, 26, 182-190. http://dx.doi.org/10.1016/j. ifset.2014.06.008.

Bhandari, B. R., \& Adhikari, B. (2008). Drying technologies in food processing (pp. 55-89). Chichester: Blackwell Publishing.

Briki, S., Zitouni, B., Bechaa, B., \& Amiali, M. (2019). Comparison of convective and infrared heating as means of drying pomegranate arils (Punica granatum L.). Heat and Mass Transfer, 55(11), 31893199. http://dx.doi.org/10.1007/s00231-019-02644-8.

Calín-Sánchez, A., Figiel, A., Hernandez, F., Melgarejo, P., Lech, K., \& Carbonell-Barrachina, A. A. (2013). Chemical Composition, antioxidant capacity, and sensory quality of pomegranate (Punica granatum $L$.) arils and rind as affected by drying method. Food and Bioprocess Technology, 6(7), 1644-1654. http://dx.doi.org/10.1007/ s11947-012-0790-0.

Cano-Lamadrid, M., Lech, K., Michalska, A., Wasilewska, M., Figiel, A., Wojdylo, A., \& Carbonell-Barrachina, A. A. (2017). Influence of osmotic dehydration pre-treatment and combined drying method on physico-chemical and sensory properties of pomegranate arils, cultivar Mollar de Elche. Food Chemistry, 232, 306-315. http://dx.doi. org/10.1016/j.foodchem.2017.04.033. PMid:28490079.

Chen, D., Xing, B., Yi, H., Li, Y., Zheng, B., Wang, Y., \& Shao, Q. (2020). Effects of different drying methods on appearance, microstructure, bioactive compounds and aroma compounds of saffron (Crocus sativus L.). Lebensmittel-Wissenschaft + Technologie, 120, 108913. http://dx.doi.org/10.1016/j.lwt.2019.108913.

Dalmau, M. E., Bornhorst, G. M., Eim, V., Rosselló, C., \& Simal, S. (2017). Effects of freezing, freeze drying and convective drying on in vitro gastric digestion of apples. Food Chemistry, 215, 7-16. http://dx.doi.org/10.1016/j.foodchem.2016.07.134. PMid:27542444.

David, L., Danciu, V., Moldovan, B., \& Filip, A. (2019). Effects of in vitro gastrointestinal digestion on the antioxidant capacity and anthocyanin content of cornelian cherry fruit extract. Antioxidants, 8(5), 114. http://dx.doi.org/10.3390/antiox8050114. PMid:31052224.

Fawole, O. A., Opara, U. L., \& Theron, K. I. (2012). Chemical and phytochemical properties and antioxidant activities of three pomegranate cultivars grown in South Africa. Food and Bioprocess Technology, 5(7), 2934-2940. http://dx.doi.org/10.1007/s11947011-0533-7.

Gao, Q.-H., Wu, C.-S., Wang, M., Xu, B.-N., \& Du, L.-J. (2012). Effect of drying of jujubes (Ziziphus jujuba Mill.) on the contents of sugars, organic acids, $\alpha$-tocopherol, $\beta$-carotene, and phenolic compounds. Journal of Agricultural and Food Chemistry, 60(38), 9642-9648. http://dx.doi.org/10.1021/jf3026524. PMid:22958080.

Giusti, M., \& Wrolstad, R. (2001). Characterization and measurement of anthocyanins by UV-visible spectroscopy. Current Protocols in Food Analytical Chemistry, (1), F1.2.1, 13. http://dx.doi. org/10.1002/0471142913.faf0102s00.

Gölükcü, M. (2015). The effects of drying methods, packaging atmosphere and storage time on dried pomegranate aril quality. Journal of Agricultural Sciences-Tarim Bilimleri Dergisi, 21(2), 207219. http://dx.doi.org/10.15832/tbd.06219.

Guiné, R. P. F., \& Barroca, M. J. (2012). Effect of drying treatments on texture and color of vegetables (pumpkin and green pepper). Food and Bioproducts Processing, 90(1), 58-63. http://dx.doi.org/10.1016/j. fbp.2011.01.003.

Hamid, T., Thakur, N. S., Thakur, A., \& Kumar, P. (2020). Effect of different drying modes on phenolics and antioxidant potential of different parts of wild pomegranate fruits. Scientia Horticulturae, 274, 109656. http://dx.doi.org/10.1016/j.scienta.2020.109656.

Hawlader, M. N. A., Perera, C. O., Tian, M., \& Yeo, K. L. (2006). Drying of guava and papaya: impact of different drying methods. Drying Technology, 24(1), 77-87. http://dx.doi.org/10.1080/07373930500538725.

Huang, L., Zhang, M., Yan, W., Mujumdar, A. S., \& Sun, D. (2009). Effect of coating on post-drying of freeze-dried strawberry pieces. Journal of Food Engineering, 92(1), 107-111. http://dx.doi.org/10.1016/j. jfoodeng.2008.10.031.

Islam, M. M., Zhang, M., Bhandari, B., \& Guo, Z. M. (2019). A hybrid vacuum frying process assisted by ultrasound and microwave to enhance the kinetics of moisture loss and quality of fried edamame. Food and Bioproducts Processing, 118, 326-335. http://dx.doi. org/10.1016/j.fbp.2019.10.004.

Karaaslan, M., Yılmaz, F., Cesur, Ö., Vardin, H., Ikinci, A., \& Dalgıç, A. (2014). Drying kinetics and thermal degradation of phenolic compounds and anthocyanins in pomegranate arils dried under vacuum conditions. International Journal of Food Science \& Technology, 49(2), 595-605. http://dx.doi.org/10.1111/ijfs.12342.

Karasu, S., Kilicli, M., Başlar, M., Arici, M., Sagdic, O., \& Karaagacli, M. (2015). Dehydration kinetics and changes of bioactive compounds of tulip and poppy petals as a natural colorant under vacuum and oven conditions. Journal of Food Processing and Preservation, 39(6), 2096-2106. http://dx.doi.org/10.1111/jfpp.12453.

Kayacan, S., Karasu, S., Akman, P. K., Goktas, H., Doymaz, I., \& Sagdic, O. (2020). Effect of different drying methods on total bioactive compounds, phenolic profile, in vitro bioaccessibility of phenolic and HMF formation of persimmon. Lebensmittel-Wissenschaft + Technologie, 118, 108830. http://dx.doi.org/10.1016/j.lwt.2019.108830.

Khan, M. I. H., Wellard, R. M., Nagy, S. A., Joardder, M. U. H., \& Karim, M. A. (2016). Investigation of bound and free water in plant-based food material using NMR T2 relaxometry. Innovative Food Science \& Emerging Technologies, 38, 252-261. http://dx.doi.org/10.1016/j. ifset.2016.10.015. 
Kroehnke, J., Szadzińska, J., Stasiak, M., Radziejewska-Kubzdela, E., Biegańska-Marecik, R., \& Musielak, G. (2018). Ultrasound- and microwave-assisted convective drying of carrots - Process kinetics and product's quality analysis. Ultrasonics Sonochemistry, 48, 249-258. http://dx.doi.org/10.1016/j.ultsonch.2018.05.040. PMid:30080548.

Liu, S., Zhu, W., Bai, X., You, T., \& Yan, J. (2019). Effect of ultrasonic energy density on moisture transfer during ultrasound enhanced vacuum drying of honey. Journal of Food Measurement and Characterization, 13(1), 559-570. http://dx.doi.org/10.1007/s11694-018-9969-z.

Ma, Y., Gao, J., Wei, Z., \& Shahidi, F. (2021). Effect of in vitro digestion on phenolics and antioxidant activity of red and yellow colored pea hulls. Food Chemistry, 337, 127606. http://dx.doi.org/10.1016/j. foodchem.2020.127606. PMid:32799168.

Mahiuddin, M., Khan, M. I. H., Kumar, C., Rahman, M. M., \& Karim, M. A. (2018). Shrinkage of Food Materials During Drying: Current Status and Challenges. Comprehensive Reviews in Food Science and Food Safety, 17(5), 1113-1126. http://dx.doi.org/10.1111/15414337.12375. PMid:33350150.

Minekus, M., Alminger, M., Alvito, P., Ballance, S., Bohn, T., Bourlieu, C., Carrière, F., Boutrou, R., Corredig, M., Dupont, D., Dufour, C., Egger, L., Golding, M., Karakaya, S., Kirkhus, B., Le Feunteun, S., Lesmes, U., Macierzanka, A., Mackie, A., Marze, S., McClements, D. J., Ménard, O., Recio, I., Santos, C. N., Singh, R. P., Vegarud, G. E., Wickham, M. S. J., Weitschies, W., \& Brodkorb, A. (2014). A standardised static in vitro digestion method suitable for food: an international consensus. Food \& Function, 5(6), 1113-1124. http:// dx.doi.org/10.1039/C3FO60702J. PMid:24803111.

Mosele, J. I., Macià, A., Romero, M.-P., Motilva, M.-J., \& Rubió, L. (2015). Application of in vitro gastrointestinal digestion and colonic fermentation models to pomegranate products (juice, pulp and peel extract) to study the stability and catabolism of phenolic compounds. Journal of Functional Foods, 14, 529-540. http://dx.doi. org/10.1016/j.jff.2015.02.026.

Orikasa, T., Koide, S., Okamoto, S., Imaizumi, T., Muramatsu, Y., Takeda, J.-i., Shiina, T., \& Tagawa, A. (2014). Impacts of hot air and vacuum drying on the quality attributes of kiwifruit slices. Journal of Food Engineering, 125, 51-58. http://dx.doi.org/10.1016/j. jfoodeng.2013.10.027.

Özcan, M. M., Aljuhaimi, F., Uslu, N., Mohamed Ahmed, I. A., Osman, M. A., Gassem, M. A., \& Salih, H. A. A. (2019). Effect of oven drying on antioxidant activity, phenolic compounds, fatty acid composition and tocopherol contents of pomegranate aril and oils. Journal of Food Processing and Preservation, 43(3), e13885. http:// dx.doi.org/10.1111/jfpp.13885.

Parikh, D. (2015, April 1). Vacuum drying: basics and application. Chemical Engineering.

Pérez-Vicente, A., Gil-Izquierdo, A., \& García-Viguera, C. (2002). In vitro gastrointestinal digestion study of pomegranate juice phenolic compounds, anthocyanins, and vitamin C. Journal of Agricultural and Food Chemistry, 50(8), 2308-2312. http://dx.doi.org/10.1021/ jf0113833. PMid:11929289.

Re, R., Pellegrini, N., Proteggente, A., Pannala, A., Yang, M., \& RiceEvans, C. (1999). Antioxidant activity applying an improved ABTS radical cation decolorization assay. Free Radical Biology \& Medicine, 26(9-10), 1231-1237. http://dx.doi.org/10.1016/S0891-5849(98)003153. PMid:10381194.

Sengul, H., Surek, E., \& Nilufer-Erdil, D. (2014). Investigating the effects of food matrix and food components on bioaccessibility of pomegranate (Punica granatum) phenolics and anthocyanins using an in-vitro gastrointestinal digestion model. Food Research International, 62, 1069-1079. http://dx.doi.org/10.1016/j.foodres.2014.05.055.

Singh, R. P., Chidambara Murthy, K. N., \& Jayaprakasha, G. K. (2002). Studies on the antioxidant activity of pomegranate (Punica granatum) peel and seed extracts using in vitro models. Journal of Agricultural and Food Chemistry, 50(1), 81-86. http://dx.doi.org/10.1021/ jf010865b. PMid:11754547.

Singleton, V. L., \& Rossi, J. A. (1965). Colorimetry of total phenolics with phosphomolybdic-phosphotungstic acid reagents. American Journal of Enology and Viticulture, 16(3), 144-158. Retrieved from https://www.ajevonline.org/content/ajev/16/3/144.full.pdf

Süfer, O., \& Palazoglu, T. K. (2019a). Microwave-vacuum drying of pomegranate arils (Punica granatum L. cv. Hicaznar): effect on quality and nutrient content. Journal of Food Processing and Preservation, 43(9), e14085. http://dx.doi.org/10.1111/jfpp.14085.

Süfer, O., \& Palazoglu, T. K. (2019b). A study on hot-air drying of pomegranate: kinetics of dehydration, rehydration and effects on bioactive compounds. Journal of Thermal Analysis and Calorimetry, 137(6), 1981-1990. http://dx.doi.org/10.1007/s10973-019-08102-1.

Tekin, Z. H., \& Başlar, M. (2018). The effect of ultrasound-assisted vacuum drying on the drying rate and quality of red peppers. Journal of Thermal Analysis and Calorimetry, 132(2), 1131-1143. http://dx.doi.org/10.1007/s10973-018-6991-7.

Tekin, Z. H., Başlar, M., Karasu, S., \& Kilicli, M. (2017). Dehydration of green beans using ultrasound-assisted vacuum drying as a novel technique: drying kinetics and quality parameters. Journal of Food Processing and Preservation, 41(6), e13227. http://dx.doi. org/10.1111/jfpp.13227.

Turkmen, F., Karasu, S., \& Karadag, A. (2020). Effects of different drying methods and temperature on the drying behavior and quality attributes of cherry laurel fruit. Processes, 8(7), 761. http://dx.doi. org/10.3390/pr8070761.

Ucar, T. M., \& Karadag, A. (2019). The effects of vacuum and freezedrying on the physicochemical properties and in vitro digestibility of phenolics in oyster mushroom (Pleurotus ostreatus). Journal of Food Measurement and Characterization, 13(3), 2298-2309. http:// dx.doi.org/10.1007/s11694-019-00149-w.

Wojdyło, A., Figiel, A., Legua, P., Lech, K., Carbonell-Barrachina, Á. A., \& Hernández, F. (2016). Chemical composition, antioxidant capacity, and sensory quality of dried jujube fruits as affected by cultivar and drying method. Food Chemistry, 207, 170-179. http:// dx.doi.org/10.1016/j.foodchem.2016.03.099. PMid:27080894.

Zhishen, J., Mengcheng, T., \& Jianming, W. (1999). The determination of flavonoid contents in mulberry and their scavenging effects on superoxide radicals. Food Chemistry, 64(4), 555-559. http://dx.doi. org/10.1016/S0308-8146(98)00102-2. 